\title{
Development and implementation of project management skills in vocational institutions
}

\section{Desarrollo e implementación de habilidades de gestión de proyectos en instituciones profesionales}

\author{
Ekaterina P. Sedykh \\ https://orcid.org/0000-0001-9612-9519 \\ Minin Nizhny Novgorod State Pedagogical University, Nizhny Novgorod, Russia. \\ Marina R. Zheltukhina \\ zzmr@mail.ru \\ https://orcid.org/0000-0001-7680-4003 \\ Volgograd State Socio-Pedagogical University, Volgograd, Russia. \\ Olga I. Vaganova \\ vaganova o@rambler.ru \\ https://orcid.org/0000-0001-8347-484X \\ Minin Nizhny Novgorod State Pedagogical University, Nizhny Novgorod, Russia. \\ Anna V. Lapshova \\ any19.10@mail.ru \\ https://orcid.org/0000-0001-7017-3589 \\ Minin Nizhny Novgorod State Pedagogical University, Nizhny Novgorod, Russia. \\ Nina V. Frolova \\ nina-frolova-asb@mail.ru \\ https://orcid.org/0000-0001-8177-4910 \\ Minin Nizhny Novgorod State Pedagogical University, Nizhny Novgorod, Russia.
}

\begin{abstract}
The purpose of the article is to analyze the experience of developing and implementing project management skills in the process of preparing students. From the methodological field, the dynamics of students' participation in project activities and the main ways of developing the project management skill are revealed. The participants of the study were teachers and students of higher educational institutions in the age category from 19 to 24 years. The results determined that the development and implementation of the skill of managing educational projects is one of the most significant areas of the development of educational activities since this soft skill allows students to adapt to professional activities most quickly and maintain competitiveness.
\end{abstract}

Recibido: 1/09/21

Aceptado: 5/11/21 
Keywords: soft skills, project management, VUCA world, vocational education, professional competence.

\section{Resumen}

El propósito del artículo es analizar la experiencia de desarrollar e implementar habilidades de gestión de proyectos en el proceso de preparación de los estudiantes. Desde el ámbito metodológico, se revelan las dinámicas de participación de los estudiantes en las actividades del proyecto y las principales formas de desarrollar la habilidad de dirección de proyectos. Los participantes del estudio fueron profesores y estudiantes de instituciones de educación superior en la categoría de edad de 19 a 24 años. Los resultados determinaron que el desarrollo e implementación de la habilidad de gestionar proyectos educativos es una de las áreas más significativas del desarrollo de las actividades educativas ya que esta habilidad blanda permite a los estudiantes adaptarse más rápidamente a las actividades profesionales y mantener la competitividad.

Palabras clave: habilidades blandas, gestión de proyectos, mundo VUCA, formación profesional, competencia profesional.

\section{Introduction}

The training of a competent specialist who can navigate in rapidly changing conditions is becoming one of the primary tasks of Russian vocational education.

In this regard, many scientists and researchers pay attention to the need for the formation of soft skills that will allow the student to become in demand on the labor market and a competitive specialist in professional activity.

In the course of training, the emphasis is shifted towards the formation of creative independence, the ability to interact, jointly solve emerging problems, search for the most rational way out of conflicts and other abilities and skills of students that contribute to the formation of their professional competence in the modern environment. One of the most significant soft skills is project management (Tsarapkina et al., 2021).

The vision allows the student to rely on the available data and see the perspective of the development of events and take appropriate actions for the most effective achievement of goals.

Understanding allows you to cope with uncertainty, because an understanding student realizes the importance of flexibility in his life, the importance of soft skills for professional self-improvement, due to which he remains a sought-after specialist (Shashlo et al., 2018).

Clarity determines the student's ability to quickly focus on the most important ways out of difficult situations (Vaganova et al., 2019). 
The quickness of reaction implies prompt decision-making, the ability to communicate effectively (Dobudko et al., 2019).

The understanding, vision and speed of reaction formed in the process of developing the project management skill allow the student not just to exist in the new modern world, but to be a leader, a competitive specialist who effectively acts in a variety of conditions and creatively achieves his goals (Aniskin et al., 2020).

A large number of students are involved in the project management process. And the implementation of the tasks is carried out in a short time. The task of the educational institution is to prepare the student for the implementation of the project in conditions of a lack of information and a small amount of time. During the implementation of the project, the student develops the ability to work in a team, the ability to serve other people, leadership qualities, the ability to argue his opinion.

Since a project is often a team effort, project management is team leadership. That is, each of the participants understands that in order to achieve the goal, coordinated activities are needed, in which minimizing conflicts and recognizing leadership roles play a significant role.

Project management allows students to form the necessary competencies, since it includes different types of activities and is a promising tool in the educational process.

Therefore, today, to achieve the highest results in the preparation of students of higher educational institutions, monitoring of the learning process in general and the development of project management skills, in particular.

\section{Theoretical framework}

During the training, students somehow face a lot of projects of different scales. And each project includes several factors, for example, such as deadline, resources (time, material, equipment...), selection of project management methods, and others.

The project includes different types of activities that are united by common features:

- focus on achieving the set goals;

- implementation of coordinated actions in each working subgroup;

- the limited implementation of the project in time, the presence of a schedule of speeches.

The signs of the project should include:

- the presence of a goal;

- difficulty; 
- specificity.

There are several types of approaches to project implementation. Among them, the classic type and Agile are distinguished. The classic way of project management involves dividing the process into several stages (without passing one stage, you can not go to the next). Usually, the stages can be represented as follows: initiation, planning, development, implementation and verification, the final stage.

During the initiation, the requirements for the project are determined. Brainstorming sessions are held among students to determine the final product. At the planning stage, students determine the content of the goal achievement process; carry out the maximum detail of goals and results. At the development stage, students are actively involved in the process of doing the work, distribute tasks among themselves, select the material necessary for the work. At the stages of implementation and verification, by the previously developed plans, the product is introduced and the process is monitored (Kharytonov et al., 2019). The final stage includes reflection and works on the main errors (Vaganova et al., 2020).

The agile approach includes compliance with established requirements and achieving certain results based on them and constant interaction within working subgroups.

Agile is a set of ideas and principles for the most effective implementation of the project (Pichugina \& Bondarchuk, 2019).

The project is not divided into successive stages, but into small subprojects that can be assembled into a single product in the future. The sequential passage of the stages is laid down in each subproject (Kidina, 2020). Thus, students will be able to get results most quickly due to time changes to individual parts of a large project. In addition, you can notice the shortcomings of a small project most quickly (Ponachugin, \& Lapygin, 2019).

Among the most popular features of the approach under consideration are adaptability and flexibility (Yarygin et al., 2019).

In the process of forming the project management skill, the most important qualities for the implementation of professional activities are formed:

- leadership (in the process of implementing the project, students distribute functions among themselves and each of them should understand that part of a successful project is a clear definition of goals and fulfillment of tasks by each of the participants) (Pinkovetskaia et al., 2020). The work execution process can be organized in such a way that each team member can perform the role of a leader at a particular stage of the project (Shcerbakova \& Shcerbakova, 2019).

Project management skill also implies the ability to motivate others to complete tasks (an important part of leadership) (Vaganova et al., 2019). 
Communication-open communication allows the team to develop trust in each other, which leads to transparency of decisions, absence or quick exit from conflict situations (Bulaeva, et al., 2018), prompt achievement of the results planned at the beginning of the project (Nagovitsyn et al., 2020).

Levels can also be allocated in the project management:

- goal setting (setting the main goal of the project) (Kosenok \& Bezuevskaya, 2019);

- the level of design (careful development of the necessary tools for the project (tools, resources, organizational structure, communication between participants and the project, etc.) (Ivanova \& Korostelev, 2019);

- the level of project implementation (correlation of project implementation requirements and the existing reality, availability of necessary resources) (Nagovitsyn et al., 2020).

Project management is a dynamic system that includes a variety of components, including: resources, results, risks, and others (Kiseleva et al., 2019).

In the modern world, project management is becoming an increasingly relevant skill among students of professional educational institutions.

\section{Methodology}

The paper presents data on the degree of students ' involvement in project activities. For several years, starting from 2017 to 2020, the results of statistical data processing were recorded in a separate table.

The study participants were students of higher educational institutions in the age category from 19 to 24 years, studying in several areas. The total number of projects carried out in the university environment and the total number of participants were highlighted. Students and projects were divided into groups.

The study allowed us to pay attention to the dynamics of students ' participation in project activities.

Also, a survey was conducted among the teachers, which allowed identifying the main factors for the development of students ' management skills soon.

The most common answers were selected from the general list of answer options.

\section{Results and discussion}

Most teachers of higher educational institutions are aware of the need to develop project management skills by the requirements of the modern labor market. In the VUCA world, 
project management is one of the key skills that allow you to increase your competitiveness (Demidov \& Tretyakov, 2016a).

A survey was conducted among the teachers, which allowed identifying the main ways to develop students' management skills soon. The results are shown in Figure 1.

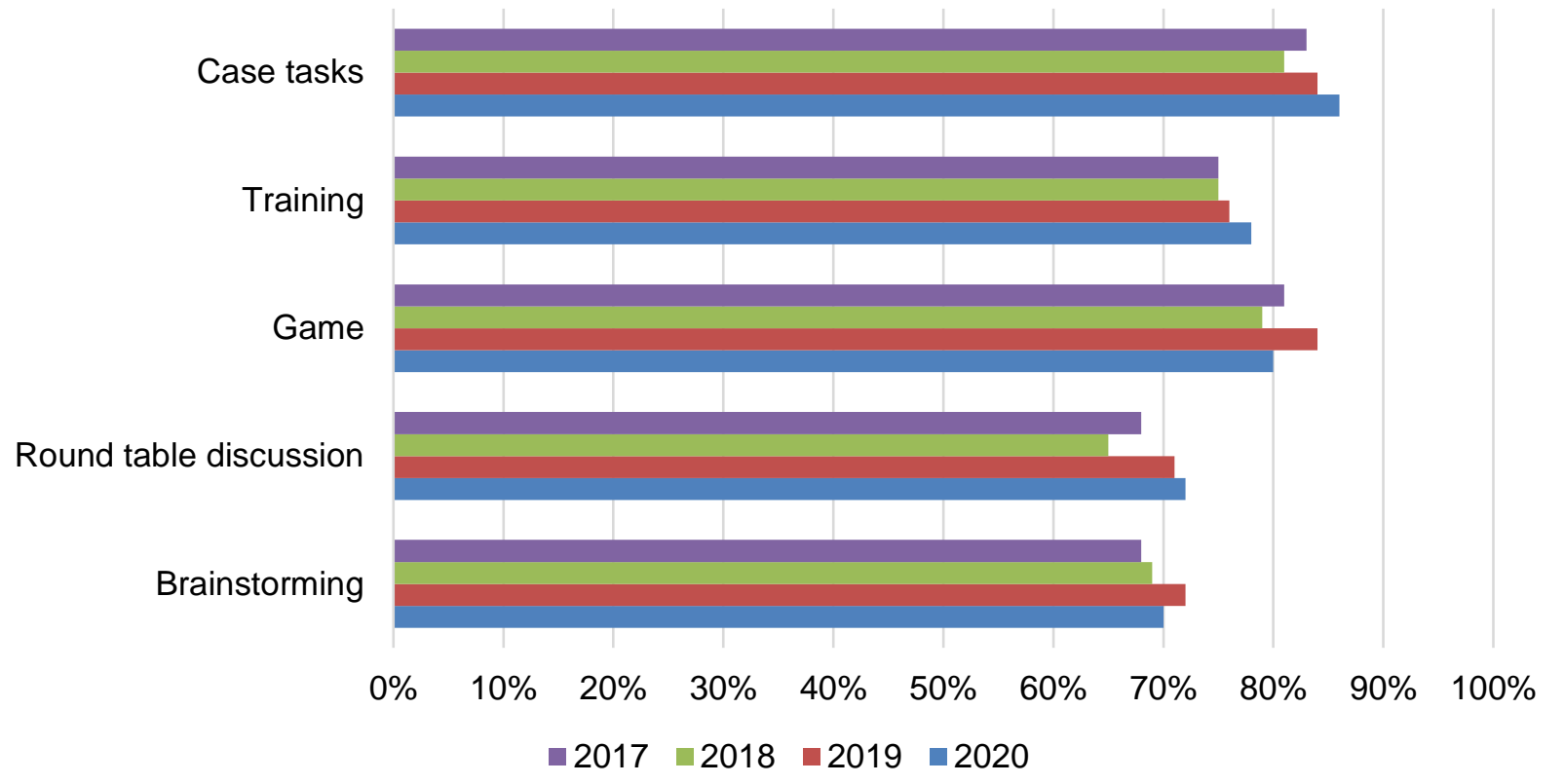

Fig. 1. The results of a survey of teachers to identify the most relevant ways to develop the project management skill.

We see that the chosen methods remain relevant for a long time. But it is worth noting that each of them is transformed by modern conditions.

In the process of organizing training, tools are used that contribute to active group activity. Time-consuming brainstorming sessions, round tables (which are held in a remote format, among others), games and case solving allow you to improve professional competencies.

Brainstorming helps to make an operational decision, in the process of participating in round tables; students are forming the skill of conducting an effective discussion.

In the process of playing and solving case problems, students distribute functions among themselves. In this process, everyone can become a leader, a performer or a controller. This is how the preparation for the implementation of serious projects is carried out.

For several years, universities have been increasing the number of competitions for student projects. Timely monitoring allows you to identify the number of their participants. 
The degree of students ' involvement in project activities is beginning to increase, as evidenced by the results of research conducted over several years.

The figure below highlights several of the most popular areas of student projects implemented from 2017 to 2020.

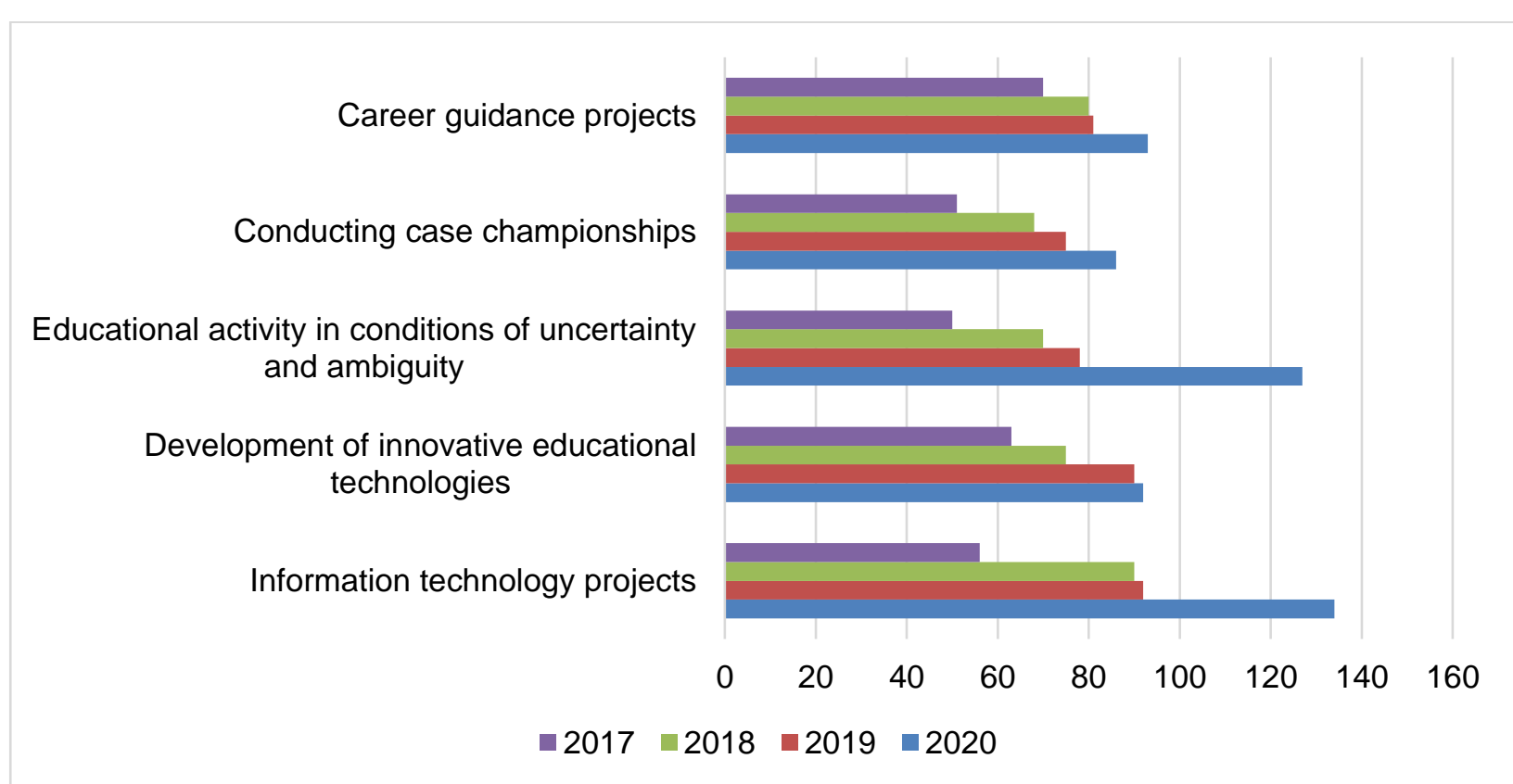

Fig. 2. Popular directions of student projects (2017-2020).

The most popular areas of student projects over the four-year period were:

- conducting case championships (organizing events held by students on a competitive basis, where each student can present their skills and the formation of competencies);

- educational activities in conditions of uncertainty and ambiguity (student projects reflecting the organization of educational activities aimed at improving its quality in new conditions);

- development of innovative educational technologies (projects dedicated to the development and implementation of new technologies in the learning process);

- projects in the field of information technologies (development and implementation of new technical means that contribute to the organization of the most effective learning process.

By 2020, the largest number of participants has been identified in projects aimed at resolving issues in the field of educational activity development in conditions of uncertainty and ambiguity. Students are interested in adapting the educational process to the conditions of the VUCA world, in which uncertainty and ambiguity are a significant part. 
It is also worth paying attention to the fact that information technologies have become an actual direction for research activities and by 2020 the interest of students is only increasing. The use of information technologies and e-learning in 2020 has become the most popular due to the forced and massive transition to a distance learning format. Students are interested in the development of this topic for the formation of the most comfortable conditions for educational activities.

It should be noted that the implementation of each direction is somehow connected with innovative technologies, electronic remote tools.

The following figure shows the percentage increase in participants in professional project competitions compared to 2016.

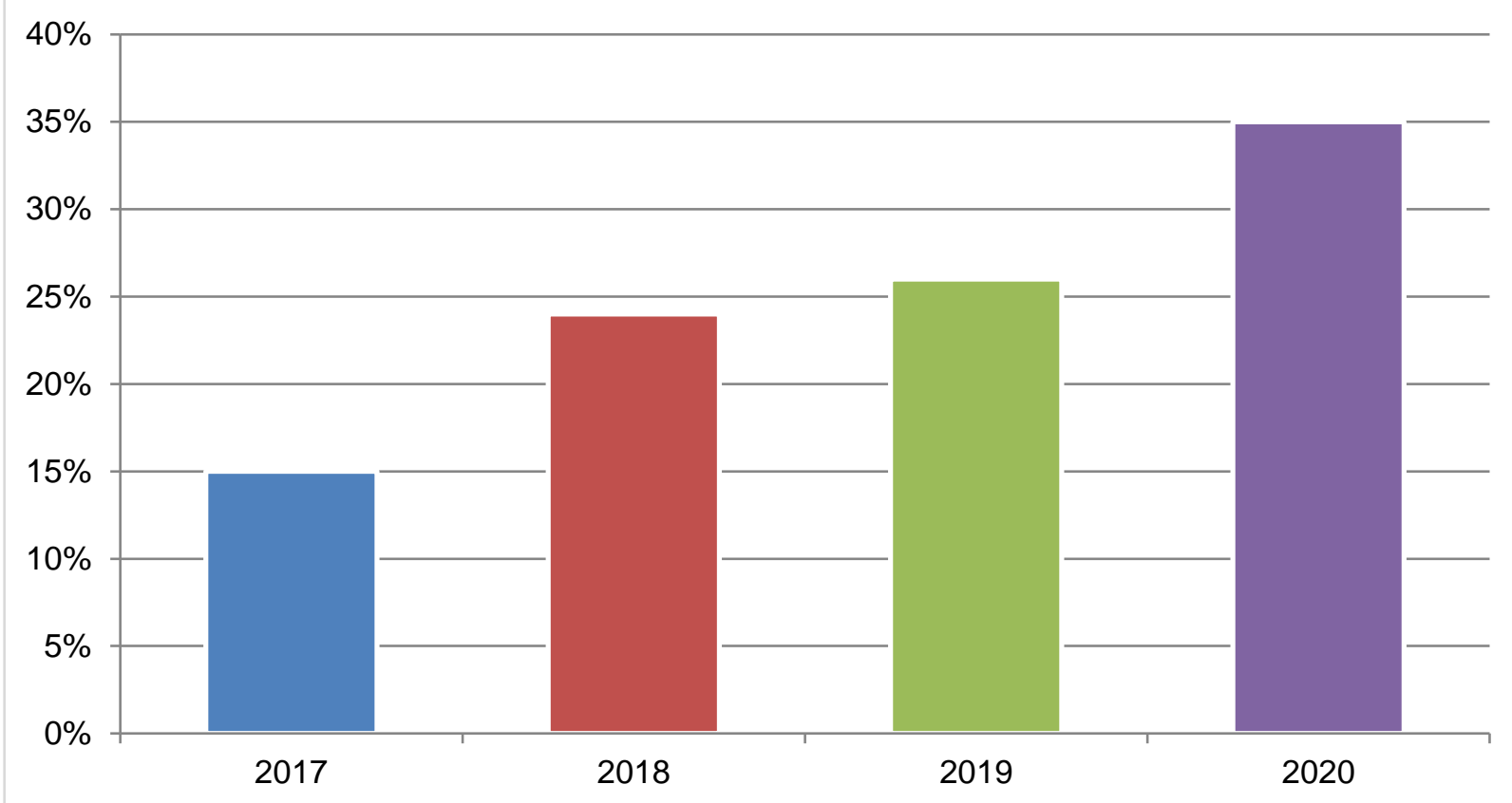

Fig. 3. Increase in the number of participants in professional project competitions (20172020)

We are seeing a steady increase in the percentage of participants.

\section{Conclusions}

The development and implementation of the skill of managing educational projects is one of the most promising areas for the development of educational activities, since this soft skill allows students to adapt to professional activities most quickly. During the implementation of the project, students are forming their leadership qualities, the ability to carry out planning and forecasting, to be a competitive specialist who effectively acts in a variety of conditions and creatively achieves their goals. 
The conducted research suggests that the need for students to participate in project competitions is growing and the number of professional project competitions is growing. The percentage of participants increases from year to year.

The data of surveys conducted among teachers of higher educational institutions make it possible to identify tools and integral components of the development of project management skills in professional educational institutions in the conditions of the VUCA world.

With the development of project management skills, a systematic vision of the situation and the process of solving important tasks is formed by students, critical thinking and the ability to work effectively in a team is formed, resolving conflict situations on time manner without compromising the final result.

\section{Bibliographic references}

Aniskin, V. N., Korostelev, A. A., Lvovna, B. A., Kurochkin, A. V., \& Sobakina, T. G. (2020). Teaching potential of integrated learning technologies Smart, Stem and Steam. Revista De La Universidad Del Zulia, 11(29), 328-336.

Arbeláez-Campillo, D., Tatsiy, V., Rojas-Bahamón, M., \& Danilyan, O. (2020). Contributions of critical thinking as a form of participation and political deliberation. Amazonia Investiga, 9(27), 5-12. https://doi.org/10.34069/Al/2020.27.03.1

Bulaeva, M. N., Vaganova, O. I., Koldina, M. I., Lapshova, A. V., \& Khizhnyi, A.V. (2018). Preparation of Bachelors of Professional Training Using MOODLE. Advances in intelligent systems and computing, 622, pp. 406-411.

Dobudko, T.V., Korostelev, A.A., Gorbatov, S.V., Kurochkin, A.V., \& Akhmetov, L.G. (2019). The organization of the university educational process in terms of digitalization of education. Humanities and Social Sciences Reviews. 7(4), pp. 1148-1154.

Demidov, A.A. \& Tretyakov A.L. (2016a). A network model of centers for ethical and legal education and civil-patriotic education and media education centers based on school libraries: the need to create, opportunities and real prospects, Media Education (Mediaobrazovanie), 3, pp. 16-22.

Ivanova, N., \& Korostelev, A. (2019). The impact of competitive approach on students' motivation in sport. Amazonia Investiga, 8(18), 483-490. Retrieved from https://amazoniainvestiga.info/index.php/amazonia/article/view/362

Kidina, I. M. (2020). Management of the pedagogical collective in the conditions of implementing distance learning. Baltic Humanitarian Journal. (Baltic Humanitarian Journal), Vol. 9 No 4 (33), pp. 93-96.

Kharytonov, E., Kharytonova, O., Tolmachevska, Y., Fasii, B., \& Tkalych, M. (2019). Information Security and Means of Its Legal Support. Amazonia Investiga, 8(19), 255-265. Retrieved from https://amazoniainvestiga.info/index.php/amazonia/article/view/227 
Kiseleva, O., Lebedev, A., Pinkovetskaia, I., Rojas-Bahamón, M., \& Arbeláez Campillo, D. (2019). Specialization and concentration of small and medium enterprises employees: Russian data. Amazonia Investiga, 8(20), 6-15. Retrieved from https://amazoniainvestiga.info/index.php/amazonia/article/view/59

Kosenok, S. M., \& Bezuevskaya, V. A. (2019). Project management at the university answering the challenges of time. Economics, Entrepreneurship and Law, 9 (4), 595-604. URL: https://cyberleninka.ru/article/n/proektnoe-upravlenie-vuniversitete-otvet-na-vyzovy-vremeni

Nagovitsyn, R. S., Vaganova, O. I., Kutepov, M. M., Kosenovich, O. V, Moeseev, Yu. V., Vorotova, M. S., \& Osipov, A. Y. (2020). Interactive Technologies in Developing Student's Motivation in Physical Education and Sport. International Journal of Applied Exercise Physiology, 9(6), 78-85.

Pichugina, G.A., \& Bondarchuk, A.I. (2019). Structure of the training case in the organization of the educational process. Humanitarian balkan research, 2(4), pp. 5-7.

Pinkovetskaia, I., Berezina, N., \& Sverdlikova, E. (2020). The main reasons for the exit of entrepreneurs from business. Amazonia Investiga, 9(26), 68-73. https://doi.org/10.34069/Al/2020.26.02.7

Ponachugin, A.V., \& Lapygin, Yu.N. (2019). Digital Educational Resources of The University: Design, Analysis And Expertise. Vestnik of Minin University, Vol. 7 (2), 5. (in Russ)

Rojas-Bahamón, M.J., Aguilar-Cruz, P.J., \& Arbeláez-Campillo, D.F. (2020). Curricular integration as a strategy to strengthen the educational process in public institutions in COVID-19 times. Revista Inclusiones, 7 (num Especial), pp. 233-241.

Shashlo, N., Petruk, G., \& Korostelev, A. (2018). Determinants of integration interaction among the subjects of the entrepreneurial innovation ecosystem of macro region. Amazonia Investiga, 7(13), 351-363. Retrieved from https://amazoniainvestiga.info/index.php/amazonia/article/view/569

Shcerbakova, E.V., \& Shcerbakova, T. N. (2019). Experience of Use of Remote Computer Technologies at The Organization of Independent Work of Students in The Conditions of a Mark and rating system. Baltic Humanitarian Journal. (Baltic Humanitarian Journal), Vol. 8, No 4 (29), pp. 192-195.

Tsarapkina, J. M., Plahina, L. N., Konoplyuk, N. V., Vaganova, O. I., \& Lapshova, A. V. (2021). The formation of bachelors' digital competencies at the university. Propositos y representaciones, 9, № SI, Article number e811.

Vaganova, O.I., Korostelev, A.A., Smirnova, Z.V., Abramova, N.S., \& Dolmatov, S.N. (2019). Improving teachers' professionalism through the development of creativity. International Journal of Innovative Technology and Exploring Engineering, 8(8), pp. 630-634.

Vaganova, O. I., Petrozitskaya, I. A., Snatovich, A. B., Odarich, I. N., \& Kirillova, I. K. (2020). Heuristic technologies of training in professional education. Amazonia Investiga, 9(27), 509-517. https://doi.org/10.34069/Al/2020.27.03.55

Yarygin, O.N., Korostelev, A.A., Akhmetov, L.G., \& Maseleno, A. (2019). Modeling of competence as a tool of goal setting for education in modern society. International Journal of Recent Technology and Engineering, 7(6), pp. 72-77. 